\section{artelogie}

\section{Artelogie}

Recherche sur les arts, le patrimoine et la littérature de l'Amérique latine

\section{$4 \mid 2013$}

Fêtes et célébrations en Amérique latine

\title{
O triunfo solene da conversão
}

\section{Eliane Cristina Deckmann Fleck}

\section{OpenEdition \\ Journals}

\section{Edição electrónica}

URL: https://journals.openedition.org/artelogie/6463

DOI: $10.4000 /$ artelogie. 6463

ISSN: 2115-6395

\section{Editora}

Association ESCAL

\section{Refêrencia eletrónica}

Eliane Cristina Deckmann Fleck, «O triunfo solene da conversão», Artelogie [Online], 4 | 2013, posto online no dia 02 fevereiro 2013, consultado o 01 dezembro 2021. URL: http://journals.openedition.org/ artelogie/6463 ; DOI: https://doi.org/10.4000/artelogie.6463

Este documento foi criado de forma automática no dia 1 dezembro 2021.

Association ESCAL 


\title{
O triunfo solene da conversão
}

\author{
Eliane Cristina Deckmann Fleck
}

\author{
"Como em suas maiores festas, preparam os \\ índios os altares com flores e velas de cera \\ silvestre, fazem arcos triunfais, nos quais \\ penduram os pássaros do ar, os animais do mato e \\ os peixes da água, dançam e tocam flautas a seu \\ modo" (Província Jesuítica do Paraguai, século
}

XVII)

Sobre aqueles que não têm nenhum conhecimento da Verdade e não têm religião"'Que ninguna cosa sienten mucho", "de ninguna cosa tienen sentimiento mui sensible, ni que les dure" - essas afirmações de um missionário jesuíta do século XVII evidenciam uma percepção cristã-ocidental de sensibilidade que acabaria por definir estereótipos como a superficialidade de sentimentos dos indígenas e a inconstância da "alma selvagem". (C.A. 1556 In: LEITE, 1954: 294) Os relatos atestam, sobretudo, a dificuldade que os religiosos tiveram em perceber as manifestações de religiosidade dos guaranis, o que fica evidenciado na afirmação de que eram "finos ateístas, sem tributar adoração à deidade alguma, pois ignoram todas igualmente (In: LOZANO, 1973: 110).

1 Dentre os primeiros registros de missionários que atuaram junto aos indígenas guaranis à época da conquista da região platina, destacam-se os dos padres Francisco de Andrada e Martin González. Andrada, em 1545, priorizou a caracterização dos "vícios" dos guaranis, informando que "[...] não têm religião gentílica nenhuma [...] não adoravam coisa nenhuma, porém, comiam carne humana dos inimigos". (In: D. H. G., 1941: 415) Já González descreve os guaranis a partir de um movimento profético, informando que "temos notícia que entre os índios tem-se levantado um, com um menino que diz ser Deus ou filho de Deus, e que com essa invenção voltam para as suas cantorias passadas, a que são inclinados por natureza". (In: CARTAS DE INDIAS, 1877: 632) Alguns anos mais tarde, em 1594, o jesuíta Alonso Barzana descreveria os guaranis como uma "nación muy inclinada a religión verdadera o falsa [...] y hasta hoy, los que sirven y los que no sirven tienen sembrados mil agüeros y supersticiones y ritos de estos maestros, cuya principal doctrina es enseñarles a que bailen, de día y de noche [...]" (Apud FURLONG, 1962: 93-94). No Capítulo X da Conquista Espiritual, de 1639, o também jesuíta Antônio Ruiz 
de Montoya assim se referiria aos guaranis : "Nunca tiveram eles ídolos, embora o demônio já lhes tivesse imposto a idéia de venerarem os ossos de alguns índios, que em vida haviam sido magos famosos [...] Tinham eles por doutrina muito certa de que no céu haja um tigre ou cachorro muito grande que, em certos fatos de raiva, devora a lua e sol. [...] Quando estes ocorriam, mostravam eles sentimento, isto é, aflição e admiração. Acham, a partir de certa observação experimental, que, entrando algum veado no povoado e não o matando, vá morrer alguém daquele bairro ou quarteirão por onde animal escapa. Tem ajudado por sua parte, o demônio [...] a corroborar essas superstições." (MONTOYA, 1985: 54)

2 Em meados do século XVII, um trecho da Carta Ânua da Província Jesuítica do Paraguai parece, no entanto, expor - de forma emblemática - algo bastante distinto das percepções dos padres Luís da Grã, Francisco de Andrada, Martin González e Alonso Barzana, revelando a peculiaridade e a originalidade da experiência reducional entre os guaranis :

Uns vieram rio Paraná abaixo em quase 200 canoas muy de fiesta y a su usanza; outros por terra nos receberam con danzas y sarao a su modo ; levantaram altares, fazendo cada redução o seu com a pobreza da terra. De trechos em trechos encontramos arcos triunfais cujo adorno era estranho : tinham deles pendentes pescados assados e crus, carne crua e assada, galinhas e aves em gaiolas, ovos e perdizes, macacos e raposas, cachorros e gatos, peles de animais e outros empalhados, cestos cheios de comida e de algodão, arcos e flechas e coisas semelhantes que costumam usar em suas maiores festas e vendo que assim costumavam fazer a su usanza, dando mostra de agradecimento, lhes reparti alguns presentes [...] Fiquei tão admirado e consolado de ver em meio aquela inculta gentilidade altares tão asseados, música tão excelente, os índios tão domesticados, as índias e as crianças tão bem ensinadas por empenho dos padres. Em cada uma das reduções fui recebido com grande festa e com singular demonstração de caridade [...] (C. A. 1641-1643 In: MAEDER, 1996: 76)

3 Para além das reflexões que se possa fazer sobre os inegáveis indícios de ressignificação expressas no registro, ele nos oferece também uma rica descrição das normas de hospitalidade indígena referidas já ao tempo da Conquista por U. Schmidl e Cabeza de Vaca, que são enfáticos nas referências à alegria e ao prazer com que os guaranis recebiam os espanhóis : "[...] llegaron a un lugar de indios de la generación de los Guaraníes los cuales, com su principal, y hasta las mujeres y niños, mostrando mucho placer, los salieron a recebir al camino [...] y de allí pasaron prosiguiendo el camino, dejando los indios de este pueblo tan alegres y contentos, que de placer bailaban y cantaban por todo el pueblo" (CABEZA DE VACA,1984: 164-165).

4 O antropólogo Bartomeu Melià, por sua vez, além de atribuir a boa acolhida que os guaranis dispensaram aos missionários jesuítas às "normas de la hospitalidad indígena", acrescenta que ela se dava também "por la curiosidad que despertaba su llegada, y por la simpatía que se establecía com esos hombres amables y desarmados que sabían acariciar a niños y viejos". (MELIÁ, 1986: 175). É, em razão disso, que Melià defende que "para los Guaranies, tal vez más que cambios, las reducciones solo presentan aparentes modificaciones y mudanzas", ressaltando que o êxito das reduções jesuítico-guaranis não se dá "a pesar de lo que eran los Guaranies, sino precisamente por lo que eran estos Guaranies". (MELIÁ, 1986: 209-210) Essa interpretação sugere que, por um lado, os guaranis reformularam a doutrina cristã, para adaptá-la a suas necessidades psíquicas e a sua sensibilidade religiosa - igualmente marcada pela devoção, fervor emocional e exaltação ritualreligiosa - e, por outro, que os missionários se valeram, mesmo "que inconscientemente y 
por la vía de la comprensión intuitiva", da peculiar "lógica socio-religiosa guarani", caracterizada por "un pensamiento altamente simbólico y bien estruturado y [por] una religión que vivía en su amplio e intenso ritual". (MELIÁ, 1986: 209-210).

5 A utilização estratégica desta lógica sócio-religiosa guarani para a introdução da ritualística e da sensibilidade devocional cristã pelos missionários que atuaram na Província Jesuítica do Paraguai é o tema deste artigo.

\section{"Aos domingos, haja sermão na igreja" para corrigir publicamente os vícios e repreender os culpados}

6 Em 1601, o Superior Geral da Companhia de Jesus decidiu reunir as regiões do Rio da Prata, Tucumã e Chile numa Província independente, com o nome de Província Jesuítica do Paraguay. ${ }^{1} \mathrm{O} 1^{\circ}$ Concílio do Rio da Prata - realizado em Assunção, em 1603 - tem, neste contexto, uma importância fundamental, por estabelecer as metas a serem alcançadas pelos missionários, fornecer as orientações e propor estratégias para o ensino da doutrina aos índios e a reforma dos costumes dos espanhóis. ${ }^{2}$ À Companhia de Jesus cabia, portanto, "domesticar essa gente bárbara através do Evangelho [...] para arrancá-los de seus costumes bestiais e implantá-los no Cristianismo" (MONTOYA, 1985: 45) ${ }^{3}$, "repreend[endo] nisso os culpados nos demais vícios públicos, corrig[indo-os] castig[ando-os] a seu tempo com amor e inteireza, especialmente, os feiticeiros [...]". (Apud RABUSKE, 1978: 27)

7 Convictos da missão que deveriam desempenhar junto "àquela gente cega", cujas almas "entenebrecidas pelas gentilidades e pelos pecados" (MONTOYA, 1985: 111) só seriam salvas com a água do batismo, ${ }^{5}$ os missionários dirigiram suas atenções aos "magos $e$ feiticeiros", que "remeda[vam] em todas as partes o culto divino com ficções e embustes [...] fraudes com que entronizar a seus ministros, a fim de que sejam a peste e ruína das almas" (MONTOYA, 1985: 104).

8 O padre Antônio Ruiz de Montoya, em 1639, observava que era "muito conveniente fazerse alguma boa demonstração pública, para confusão dos sacerdotes desses ídolos e desengano dos povos [... Tirado esse estorvo, aquela gente começou a freqüentar com assiduidade a igreja, e os cristãos, a confissão." (MONTOYA, 1985: 108-109) Recorrendo amplamente à imaginação em seus sermões - para comover e inculcar medo e horror - os missionários passaram a atribuir aos demônios a responsabilidade pelos comportamentos condenáveis e, consequentemente, pelas punições divinas que recebiam os que roubavam, cometiam adultério ou deixavam de freqüentar a missa.

Num domingo, estando todos a ouvir o sermão e a missa, somente esse índio ficou em sua granja. Começaram então ali os demônios a dar vozes como de vaca, bramidos como de touro e mugidos como de bois, bem como imitar as cabras. Espantado, o pobre índio se recolheu a sua choça, sem se atrever a sair de lá, por tomado de medo. Vindo gente à tarde, o índio lhes contou a respeito de sua aflição e, andando eles por aquelas plantações, viram várias pegadas de animais e uma delas de formato tão pequeno, que parecia ser de uma criança recém-nascida. 0 pior, contudo, foi que (os demônios) deixaram toda aquela plantação amarelecida e como se um fogo a tivesse chamuscado no domingo seguinte aconteceu o mesmo. [...]. Só não se tratou de confessar-se aquele índio mal habituado. Pediramme remédio e, depois da missa, eu fui até aquele posto [...]. Revesti-me de sobrepeliz e tomei na mão a água benta e, em nome de Jesus Cristo [...] mandei-lhe (ao demônio) que fosse embora daqueles lugares e que em povo algum fizesse dano. Pus num copo fechado um pedaço da sotaina de Santo Inácio e nunca mais voltou o 
demônio. Levei comigo ao povoado aquele índio, que fez uma boa confissão e, de lá em diante, foi cristão bastante exemplar. (MONTOYA, 1985: 102-103)

As referências à atuação comprometedora dos "magos e feiticeiros" não se limitaram, no entanto, às Cartas Ânuas ${ }^{6}$ das primeiras décadas do século XVII, sendo tema recorrente nas cartas seguintes, como se pode constatar nesta passagem de uma carta da década de setenta do século XVII : "Podíamos lograr todavía mucho más de estas naciones por hacerlas cristianas, si no los acobardasen [a los salvajes] los muchos hechiceros con sus embustes, temibles por su trato con el demonio, alegando ellos que irgan a perder su libertad [al hacerse cristianos]." (C.A. 1672-1675 In: LEONHARDT, 1927: 45)

Estas ações, que comprometiam o trabalho da conversão, deveriam ser combatidas através da contínua pregação "sobre algum mandamento com muitas repetições. Aos domingos haja sermão na igreja" (Apud RABUSKE, 1978: 32), para que os indígenas conhecessem o "verdadeiro Deus" e fossem orientados sobre os "enganos do demônio" e os "ardis dos magos feiticeiros". Empregados para instruir os indígenas nos princípios da fé cristã, para fortalecê-los no "combate aos inimigos invisíveis" e para afastá-los das tentações "por medio del escudo de la fe y del santo temor de Dios" (C. A. [1673-1639] In: MAEDER, 1984: 28-29), os sermões deveriam atender à recomendação de que "[...] Sejam tais que se lhes declare algum mistério, artigo ou mandamento, repetindo-o muitas vezes $e$ usando de comparações e exemplos" (Apud RABUSKE, 1978: 26). ${ }^{7}$

11 Como se pode constatar, à manifestação pública de arrependimento - ou à confissão do pecador, se seguia uma mudança de conduta, considerada fundamental para o sucesso do trabalho do missionário, devido aos efeitos que causava sobre os demais indígenas. Mas os procedimentos de persuasão adotados pelos missionários não se limitavam a amedrontar, como se pode constatar no envolvimento dos indígenas na organização de procissões solenes ou, então, no uso de instrumentos musicais durante as missas : 8

\section{Que sejam solenes as celebrações "para inculcar más a los indios el respeto a lo sagrado"}

12 Na 5 ${ }^{\mathrm{a}}$ Carta Ânua, encontramos a seguinte recomendação feita pelo padre relator : "Para inculcar más a los indios el respeto a lo sagrado se escogen los más aptos entre los hijos de los indios para ayudantes en las funciones sagradas. [...] Así lograron estos solitarios Padres organizar este año la solemne celebración de la fiesta de Corpus Christi con su correspondiente procesión eucarística; en la cual era de ver el entusiasmo de la gente [...]" (5ª CARTA ÂNUA In: MANUSCRITOS DA COLEÇÃO DE ANGELIS [MCA], 1951: 333). ${ }^{9}$

13 Na mesma Ânua, encontramos a informação de que os missionários dirigiam aos indígenas "las contínuas instrucciones privadas y públicas, la explicación del catecismo, y las solemnes ceremonias según el rito romano en la administracion de los Santos Sacramentos" pois, haviam observado "que esta gente sencilla se impresiona no poco por la esplendidez del aparato externo. Por esto se dirige nuestro más solicito empeño para que, con ocasión de las festas mayores, penetre el correspondiente mistério en la inteligencia de los neófitos y quede grabado" (5 CARTA ÂNUA In: MCA, 1951: 333).

14 Também o padre Montoya refere-se às "solemnes ceremonias", através das quais "adiantavam muito os novos cristãos com a contínua pregação do Evangelho e iam-se estabelecendo entre eles ótimos costumes. Um deles, e bastante louvável, era o de que de manhã 
bem cedo todos assistissem a Missa [celebradas] com canto de órgão e com instrumentos musicais muito bons" (MONTOYA, 1985: 124). ${ }^{10}$ Recursos cênicos e instrumentos musicais parecem ter sido largamente empregados pelos missionários, como se pode constatar em várias passagens das Cartas Ânuas. Em uma delas, a de 1641 a 1643, encontramos o registro de que "Los domingos y fiestas se celebran con toda solemnidad, misa cantada $y$ sermón [...] en las iglesias que están muy bien adornadas con el adorno posible según el aderezo de la tierra [...] Cuando hacen señal para llevar el Santísimo al doliente aderezan la casa con flores, barren y componen las calles con ramos, y todos comúnmente traen sus velitas de cera silvestre y acompañan al señor con gran devoción y música de chirimía" (C.A. 1641-1643 In: MAEDER, 1996: 77) Na mesma Ânua, o Provincial Pe. Francisco Lupercio de Zurbano refere que os indígenas haviam realizado uma procissão que levava "en triunfo la imagen de la Virgen por calles y plaza, por debajo de los arcos artisticamente adornados com flores $y$ ramas del campo, entre súplicas y cánticos sagrados [...] estas sus prácticas religiosas parecerán, no pequeñeces, sino cosas grandes, no vilezas, sino cosas sublimes, a lo menos delante de Dios, el cual sabe apreciarlas en su justo valor" (C.A. 1641-1643 In: MAEDER, 1996: 93-94).

Em outra Ânua, encontramos a descrição da alegria demonstrada pelos indígenas : "Entre los objetos sagrados había yo traído uma imagen de la Virgen Santisima, pintada, para que fuera colocada en el templo. Al saber esto, resolvieron los índios, en su alegria recibirla con la más grande solemnidad posible. El templo destinado para ello fué adornado con sus acostumbradas flores y guirlandas, las calles, plaza y aceso, por donde tenia que venir con arcos triunfales. Todavia no habiamos llegado al pueblo, cuando todos em solemne procesión salieron al encuentro de la imagen, saludándola, los niños y las niñas cantando, los demás a son de música, tocando flautas y timbales a su usanza, y el sacerdote recitando las preces del ritual [...]" (5a CARTA ÂNUA In: MCA, 1951: 353-354).

As transcrições acima apontam não apenas para "indios tan domesticados" verdadeiramente devotados às práticas rituais cristãs, mas também para as concessões que os missionários fizeram "para atraerlos mejor [...] al suave jugo de la ley evangelica y reformación de suas bárbaras costumbres."' (C.A. 1641-1643 In: MAEDER, 1996: 122) Revelam, igualmente, que os indígenas guaranis encontraram nas reduções um espaço privilegiado para continuarem praticando a sua religiosidade e, principalmente, sendo guaranis - tocando "flautas y timbales a su usanza", celebrando "con danzas y sarao a su modo", adornando templos e arcos triunfais com "sus acostumbradas flores y guirlandas ou com "adornos extraños", o que é admitido pelos próprios missionários jesuítas, que reconheciam "la particularidad que tiene esta nueva iglesia."' (C.A. 1637-1639 In: MAEDER, 1984: 74)

Estas práticas tradicionais de celebração indígena - com "seus arcos decorados com adornos estranhos" também foram registradas pelo padre Montoya que, ao destacar a "devoção e [o] asseio" com que as procissões e festas eram realizadas nas reduções, sugere não só a efetiva conversão, mas também a assimilação de padrões de higiene e de conduta civilizada pelos indígenas : "Fizeram-se igrejas de fácil construção, de grande capacidade ou espaço e vistosas, e renovaram-se os instrumentos musicais [...]. Nelas colocamos o Santíssimo Sacramento, cuja festa - o "Corpus Christi" - se comemora com pobreza, mas também com devoção e asseio. Preparam os índios os altares (especiais para dita festa), e fazem os seus arcos (!), nos quais penduram os pássaros do ar, os animais do mato e os peixes da água [...]". (MONTOYA, 1985: 144)

Decorridos quase sessenta anos desde este registro, o padre Antônio Sepp assim se referiria - na última década do séc. XVII - às festividades natalinas realizadas na 
redução sob sua responsabilidade : "Natal [...] Para que o sacrossanto mistério também se apresentasse aos olhos edifiquei sobre o altar um presepiozinho. Ainda que nada esplêndido, os indios o contemplam repletos de júbilo e o veneravam com pasmosa devoção. Para mais os afervorar e atrair, exibi com muita graça uns dansarinos (sic) masculinos, que alegrassem $e$ alentassem o Menino Jesus ao som da cítara. Feito isso, os meus pequenos executaram em sua língua indígena um canto geórgico-pastoril, enquanto os Anjos embalavam Jesus Infante no berço em que dormia. Tudo isso, como adverti, suscitara terníssima devoção na alma dos índios, em virtude da qual me trouxeram, lá das montanhas, cera e mel bastante para o fabrico de velas a serem usadas cada dia". (SEPP, 1980: 125) Ele continua, informando que procurou "suscitar sentimentos de piedade nos índios por meio de cenas teatrais a esta gente rude [...] para levar à cena episódios da vida dos santos [...]". (SEPP, 1980: 243) ${ }^{11}$

19 Mais do que reproduzir um padrão narrativo das Ânuas, nas quais a conversão aparece associada às demonstrações de devoção religiosa, este registro feito pelo padre Sepp no final do século XVII evidencia, mais uma vez, as apropriações e as bricolagens que compõem o cenário reducional, em que missionários e indígenas atuaram ativamente "para combinar os fragmentos mais esparsos" e as "práticas mais incompatíveis", através da experiência dos sentidos. (GRUZINSKI, 1993: 79) Crianças que entoam cantos geórgico-pastoris em "sua língua indígena" e adornam a igreja com velas feitas de cera e mel [provenientes das montanhas] parecem se somar- sem qualquer comprometimento da percepção de redução idealizada pelos missionários - às "flautas y timbales a su usanza", as "danzas y sarao a su modo" e os arcos triunfais com "sus acostumbradas flores y guirlandas e "adornos extraños" registrados em outras Ânuas.

As festas religiosas eram, segundo relato do padre Montoya, antecedidas por um período de preparação, marcado pelo jejum, pela penitência e, sobretudo, pela tensão interior - a angústia - que levava à demonstração pública de arrependimento e à confissão dos indígenas : "Ao raiar do dia assistem missa o ano todo e, depois de haverem estado na igreja, dirigem-se ao trabalho, que obtém bons resultados a partir da preparação tão religiosa. [...] Comungam os que têm capacidade quatro vezes no ano em que há jubileu, sendo preparados para tanto com sermões e exemplos, jejuns, disciplinas e outras penitências![...] Celebram eles as festas principais, com mais devoção que aparato, e é por causa de sua pobreza geral e da de suas igrejas"12 (MONTOYA, 1985:169).

21 Cerca de sete anos antes, na Carta Ânua de 1632-1634, ao descrever a visita do então Governador, o padre Diego de Boroa já havia destacado que : "Los muchachos están en la música y toda policia y costumbres cristianas tan diestros y bien enseñados, que admiran y edifican a las ciudades, donde algunas veces acontece concurrir para celebrar alguna fiesta. Y en una ocasion de estas dijo el governador de la Asumpsion, delante de todo el pueblo, verguenza nuestra es que estos indios los hagan en todo mejor que los hijos de los españoles". (C.A. 1632-1634 In: MAEDER, 1990: 123)

Em 1639, o fervor com que os indígenas se dedicavam aos rituais cristãos voltaria a ser destacado : "Estavam todos de joelhos, tendo as mãos postas e os olhos fixos no chão. Fizeram um ato fervoríssimo de aborrecimento a toda a crença vã idolatria, abraçando somente a verdadeira doutrina [...] e pedindo perdão em altas vozes a Deus, o que fizeram com tanta devoção e sentimento, que nos comoveram até as lágrimas". (MONTOYA, 1985: 108) 


\section{A igreja, um espaço regrado para a emoção religiosa dos fiéis}

23

\section{Passados alguns anos, o cenário descrito por Montoya não parece ter se alterado, já que na Ânua de 1663 encontramos o registro de que os indígenas não só viviam como cristãos, como também eram "religiosos observantes", suscitando admiração e contentamento, pois onde antes "reinaba la barbarie, se ve ahora el fervoroso espíritu de la Iglesia primitiva":

\begin{abstract}
Es de ver esta vastisima província de los indios del Paraguay, y mueve a derramar lágrimas de ternura el acordarse, como estos montes tupidos, y estos escondrijos de las selvas antes estaban consagrados a un estúpido culto idolátrico, y ahora, gracias al sudor y trabajo de nuestros Padres, se ve allí una dilatada miés evangélica, madura para la recolección, consistiendo ella más bien de ángeles, que de hombres mortales. Donde antes reinaba la barbarie, se ve ahora el fervoroso espíritu de la Iglesia primitiva, siendo el caso que estos neófitos no sólo viven como cristianos, sino como religiosos observantes, frecuentan la iglesia, oyen atentamente la explicación de la Palabra de Dios, y practican la virtud. Parece que son cristianos viejos, nacidos en famílias creyentes. Ya no hay costumbres viciosas, y ni escándalo público. No hay odios. Todos viven en paz y harmonía. Desaparecieron por completo los vícios característicos del indio: las peleas, los incestos, los amancebamientos y las borracheras. Han trocado sus costumbres gentílicas con una vida conforme a la enseñanza cristiana, teniéndo ellos ahora el constante anhelo de progresar en la virtud. En verdad, este fervor cristiano de los indios es capaz a avergonzar a los europeos, y hacerlos reflexionar (C. A.1663 In: LEONHARDT, 1927:
\end{abstract} 14-15)}

Nessa mesma Ânua, as novas condutas e a função que a igreja viria a desempenhar para aqueles que haviam abandonado "sus costumbres viciosas" e adotado "una vida conforme la enseñanza cristiana" - parecem se confirmar diante da atitude que os indígenas tomaram - acorreram ao templo para rezar -, ao serem informados da iminente ameaça à redução : "Al llegar al pueblo la noticia de esta desgracia, en lugar de levantar el grito al cielo, como suele hacerlo gente de menos juicio, ellos, por lo contrario, acudieron a la iglesia, para alabar a Dios, por el castigo que les había enviado, esperando en su bondad, que tendría misericordia de ellos"13 (C.A. 1663 In: LEONHARDT, 1927:102).

Como se pode constatar, nesses registros feitos pelos missionários, a igreja ultrapassou a sua condição de "discurso arquitetônico" e de "signo fixo do poder institucional", constituindo-se em espaço, por excelência, das manifestações da sensibilidade religiosa da "nueva Cristandade". ${ }^{14}$ A igreja era, efetivamente, um espaço consagrado, um domínio santo, "onde certas regras est[avam] em vigor", no qual eram executados certos "gestos regulados, simbólicos, que figuram ou actualizam realidades misteriosas no decurso de cerimônias". Nela, "a emoção religiosa intensa faz-se acompanhar de uma representação [...] de um espetáculo que se desempenha cientemente, mas que, todavia, não é de forma alguma embuste ou divertimento". (CAILLOIS, 1988: 151-154)

A participação ativa e entusiasmada dos indígenas na preparação das festividades, nas missas e procissões é constantemente exaltada nas cartas dirigidas ao Provincial e ao Padre Geral da Companhia de Jesus, tanto para reafirmar as estratégias de conversão adotadas e para publicizar exemplos e virtudes a serem observadas, quanto para relatar os castigos que se abatiam sobre os que se desviavam da igreja e da praça. Deve-se, contudo, ter presente que estas informações estavam condicionadas aos propósitos das Ânuas, que apresentam "sólo algunos rasgos que prueban la profunda piedad de los neófitos, y 
pueden edificar a los de la Compañía", com a finalidade de impressionar "hasta los enemigos de la Compañía y de estas reducciones de indios". (C. A. 1672-1675 In: LEONHARDT, 1927: 19)

$\mathrm{Na}$ documentação jesuítica, tanto a igreja, quanto a praça são apresentadas como espaços que evidenciam o êxito do projeto de conversão dos indígenas, por reunirem os convertidos e excluírem os que resistiam "à Palabra de Dios", apegados ao "antigo modo de ser". ${ }^{15} \mathrm{~A}$ igreja, apesar de localizada em "este último rincón del mundo", é descrita como o espaço de demonstração de genuína piedade e da devoção "desta gente hacia la divina Eucaristía [...] la conclusión de su hermosa iglesia, lo mismo que la procesión de Corpus hecha con la pompa posible en este último rincón del mundo. [...] Lo suplen todo con su fervorosa piedad y con adornos sacados del monte. Por lo mismo, cuando el Santísimo es llevado a los enfermos, se limpia y adorna el camino y lo acompañan ellos con toda solemnidad." (C.A. 1637-1639 In: MAEDER, 1984: 86) Em 1639, Montoya registrou os cuidados com a ornamentação da igreja - instalada em meio às "selvas y peñas" - e as demonstrações de fervor religioso dos indígenas da redução de Loreto durante a visita do Governador de Assunção : "Llegó acá precisamente por las fiestas de Navidad [...] Entró en la iglesia que es muy grande, y muy hermosa, vió el esplendido altar mayor, las muchas velas incendidas, todo perfumado de bálsamo, oyó el canto sagrado, acompañado con la orquestra de los instrumentos, observó la gran modestia y piedad de los indios, todos decentemente vestidos, y quedó profundamente sorprendido, no habiendo esperado tanto aparato entre las selvas y peñas. [...] Más solemnidad no se encuentra ni en Madrid". (MONTOYA, 1989: 97)

Estes registros evidenciam a importância que a igreja passou a ter nas reduções jesuíticas, enquanto espaço de manifestação da sensibilidade religiosa cristã, em especial, durante as missas, procissões, festas e penitências. Em relação ao espaço público - a praça-, este deixou de ser o lugar onde se forjava tradicionalmente a cultura guarani, para se transformar em espaço da consagração do ritual litúrgico cristão, de eliminação dos "restos de paganismo" e de "reforma de costumbres", como registrado pelo padre Montoya: "Terminada esta prática ou exercício, um dos padres subiu num pequeno tablado que se tinha feito na praça, para que todos, também as mulheres $e$ crianças, pudessem ver o desengano naqueles ossos frios, que o padre thes mostrou, indicando os nomes de quem haviam sido. Foi estranho o regozijo do povo, por ele perceber com os olhos desfeito de público o engano tão grande de corpos, que todos confessavam viverem. Com isso todos à porfia se meteram a buscar e trazer lenha, para queimá-los, e assim se fez em minha presença, a fim de evitar que guardassem para si algum osso e a partir dele procedessem no seu ardil" (MONTOYA, 1985: 108-109).

Embora a participação nas missas não possa ser enquadrada, em seu sentido estrito, como uma prática sacramental, ela era percebida como indicador da inserção dos fiéis nas práticas rituais católicas. Como assinalado por Lebrun, "o comparecimento obrigatório à missa aos domingos e dias de festa caracteriza, por excelência, a participação na Igreja Romana. [...] Assistir à missa deixou de ser uma devoção entre muitas outras e a participação dos assistentes no divino sacrifício passou doravante a ocupar o centro de toda vida espiritual". (LEBRUN, 1991:73-77)

30 Uma passagem extraída da "Conquista Espiritual", do padre Montoya, expressa bem este aspecto : "Adiantavam muito os novos cristãos com a contínua pregação do Evangelho $e$ iam-se estabelecendo entre eles ótimos costumes. Um deles, e bastante louvável, era o de que de manhã bem cedo todos assistissem a Missa e logo depois fossem trabalhar em suas lavouras. Com esse santo exercício experimentaram aumento de bens, tanto espirituais como temporais." (MONTOYA, 1985: 102). Na continuidade do registro, o jesuíta, não apenas 
enfatiza a relação entre a assistência às missas e os benefícios materiais e espirituais que decorreriam desta prática, mas especula sobre os sentimentos experimentados pelos indígenas virtuosos e por aqueles que se viam excluídos da igreja :

Era o seguinte nosso modo de proceder: - Visitávamos, ao amanhecer, os enfermos, sendo que logo mais se dizia a missa, com sermão, após o Evangelho. Em seguida mandávamos embora os gentios ou não batizados: determinação que eles sentiam não pouco, por se verem tirados da Igreja como cachorros, nisso invejando os cristãos que nela ficavam. (MONTOYA, 1985: 57)

Continuava um destes índios a fugir da doutrina e dos sermões [...]. Certo dia ele passou por um menino que, por sua pequenez, mal sabia andar ou soltar a língua, para falar. Perguntou o índio a este: 'Menino, para onde vais com tanta pressa?' Como se fosse de juízo maduro, o pequeno respondeu: 'Vou escutar a palavra de Deus, que na igreja pregam os padres. Não quero ficar fora dela como os animais. (MONTOYA, 1985: 186)

Neste último registro, a imagem de que os que ficam fora da igreja são animais - e que são tratados como tal - se prestará para desqualificar - pela imagem e pelo discurso os ainda não convertidos. A obra de Montoya, a Conquista Espiritual, refere várias situações em que é reafirmada a importância da assistência à missa e as punições aos ausentes. A primeira informa que certo índio não convertido foi punido com a morte : "Certo moço de nenhuma devoção fugia invariavelmente da assistência à missa, mesmo nos dias em que a Igreja o manda. [...] Vencido por forte tentação num dia de festa arrastou ele em sua companhia a um outro, sem que lhe permitisse voltar e assistir à missa. [...] Mas ele, arrependido daquele que perdera, tinha a vontade de lograr a este. Despedindo-se do companheiro e a poucos passos dados, ouviu que aquele seu tentador aos gritos estava pedindo socorro. Com isso olhou para trás e notou que a esse tinha-o preso um tigre feroz, despedaçando-o com ânimo raivoso. Fugiu ele próprio do perigo e apressou-se em avisar a aldeia do caso. Em sua conseqüência se reuniu a gente do povo, foi ver o acontecido e achou que o tigre já havia devorado grande parte do moço. Tornou-se conhecido esse castigo e ele serviu de exemplo para os demais". (MONTOYA, 1985: 195)

Há ainda outra situação em que fica evidente a associação entre a não conversão e a punição divina : "Advertido do caso, o padre foi em pessoa vê-los e convidá-los, bem como conduzi-los à igreja, porque mesmo depois de tanto tempo ainda não sabiam onde ficavam os umbrais dela. [...] Voltando, porém, à sua dureza antiga, prosseguiram em ausentar-se do povoado, enquanto os demais rezavam na igreja. Sobreveio-lhes, porém, o castigo, ao reentrarem em casa, pois assaltou-os um tremor e acidente (!) tal, que ali mesmo tombaram por terra e, ainda que o padre aparecesse com toda a pressa, ainda mais depressa tratou a morte de desterrá-los desta vida, e até do paraíso". (MONTOYA, 1985: 225)

As Ânuas também trazem abundantes registros sobre os castigos que se abatiam sobrem os indígenas que resistiam aos ensinamentos e à adoção das novas condutas, faltando à missa e às festas religiosas : 16 "Mostrava un indio poco respecto a las fiestas y en una de ellas estava para ir a pescar amonestaronle los suios que diese la vuelta con tiempo pues era fiesta y le obligava la misa, mas el respondió colérico en desacato de los misterios sagrados que no le avian de dar de comer ni la fiesta ni la misa y asi no hizo caso y se fue ; volvía despues muy ufano a su casa y cargado de su presa mas no quiso Dios la lograse porque la hizo en él repentinamente la muerte y caio de su estado el difunto sobre sus mesmos peces." (In: DHA, 1924: 149) em destacar os sucessos extraordinários, também foram registrados os efeitos que estas 
punições exerciam sobre os demais indígenas: "Otra moçuela de hasta 17 años solía también falta en la guarda de las fiestas y de la iglesia cuando las demas acudían reprehendiola varias vezes el Padre pero sin fruto. Fuese un día festivo a los montes con otras compañeras y engolocinada en algunas frutas silvestres se remontó alejandose de la compañía; mas - como tardase la buscaron por el rastro y despues acá se han hecho exquisitas diligensias y nunca han podido descubrir de ella ni pelo, ni hueso. Tuvolo todo el pueblo por castigo del cielo y atemorizado con él venera con grande religión los días dedicados al culto divino". (In: DHA, 1924: 145)

As passagens desta Ânua se tornam ainda mais significativas, quando encontramos a admissão pelos missionários de que "lo que no pudieron conseguir medios humanos lo alcançaron los divinos con algunos espantosos castigos que exercito N. Señor en unos y otros, que por ser semejantes a los que en otras reducciones se han escrito no se repiten, $y$ como les inculcan siempre los Padres - que todos estos sucesos acontecen por ordenación divina conviven grande horror a la culpa y asombro de la divina justicia y se han seguido muchas señaladas conversiones por este medio". (In: DHA, 1924: 200)

Esta passagem nos leva a refletir sobre a máxima de Weber, segundo a qual "Os agentes sociais obedecem à regra quando o interesse em obedecer a ela suplanta o interesse em desobedecer a ela". ${ }^{17}$ (WEBER apud BOURDIEU, 1990: 96) Oportuna aqui é a observação de Branislawa Susnik que, referindo-se aos guaranis, afirma que "los indígenas son esencialmente los explotadores oportunistas de su ambiente dentro de una pautada o tradicional factibilidad cultural; si ocurre un cambio, natural o provocado por las circunstancias externas, los indígenas buscan primordialmente satisfacer sus exigencias subsistenciales, implícito un cambio sócio-cultural". (SUSNIK, 1990: 125)

Considerando que os guaranis se integraram às celebrações religiosas cristãs, pode-se creditar a "desobediência" às condutas culturais tradicionais ao interesse na "obediência" a um "novo sistema de disposições para a prática", na medida em que "a conformidade da prática com a regra" promove "um lucro simbólico suplementar". (BOURDIEU, 1990: 97) Esse "lucro simbólico" se configuraria como a garantia da cura [face às epidemias que assolavam as reduções] ou, em caso da não-cura, da boa morte e da vida eterna prometidas pelos jesuítas. De acordo com Bartomeu Melià, os guaranis possuíam "una sociedad impregnada de una peculiar lógica socio-religiosa, un pensamiento altamente simbólico $y$ bien estruturado y una religión que vivía en su amplio e intenso ritual, el sacramento de la vida perfecta en la 'tierra sin males"'. (MELIÁ, 1986: 210) Em razão disso, teriam garantido a "manutenção da ordem simbólica", adaptando a doutrina cristã a sua vivência religiosa, no contexto reducional. Ou então, como se referiu Viveiros de Castro aos Tupinambás: "Faziam tudo quanto lhes diziam profetas e padres - exceto o que não queriam", mesmo porque o faziam segundo seus próprios termos. (VIVEIROS DE CASTRO, 1992: 38)

Há que se considerar, sem dúvida, que a obediência à nova regra implicava "assimilar tudo que era importante para ser cristão" (KARNAL, 1989: 229), o que permitiu que os índios continuassem sendo índios "desde que entrassem na fila e venerassem a presença de Cristo no ostensório que ia à frente". (KARNAL, 1989: 168) No entanto, "a ação reconfortante e vivificante" produzida pela cerimônia pública não pode ser minimizada na medida em que reafirmou sentimentos religiosos que "abandonados a si mesmos, arrefeciam". (DURKHEIM, 1989: 264). Em razão disso, concordamos com Kern, quando afirma que "não se deve insistir na idéia de uma conversão superficial do indígena, pois foi sempre característica dos guaranis, a sua religiosidade intensa", assim como "a completa convergência [...] para os problemas do além". (KERN, 1982:102; 105) 
do homem ordinário, que recria, no cotidiano, práticas de vida. A isso o autor chamou de reinvenção do cotidiano, que "é astuciosa, é dispersa, mas ao mesmo tempo [...] se insinua ubiquamente, silenciosa e quase invisível, pois não se faz notar com produtos próprios, mas na maneira de empregar os produtos impostos por uma ordem dominante" (CERTEAU, 1994: 39). Ao analisar aspectos da história construída no cotidiano por indivíduos desprezados como protagonistas desses relatos históricos, Certeau resgata-os como personagens que, através de táticas, organizam as "maneiras de jogar em campo alheio", das quais deixam vestígios que apontam para marcas de 
subjetividade nas ações que desenvolvem. Referindo-se aos usos e consumos de "bens culturais", o jesuíta francês observa que "os conhecimentos e as simbólicas impostas são objeto de manipulação pelos praticantes que não são seus fabricantes", das quais resultam "procedimentos de consumo combinatórios e utilitários", caracterizados por uma criatividade tática e bricoladora (CERTEAU, 1994: 95).

Ao considerarmos a experiência reducional numa perspectiva inter-relacional, a compreendemos como um processo de articulação e de negociação, no qual os sujeitos atuaram com suas experiências e, de modo fundamentalmente criativo, reinterpretaram um discurso recebido, produzindo um novo discurso e reapropriandose do espaço organizado. Não desconhecemos, no entanto, que os saberes etnológicos, geográficos e científicos de que os missionários eram detentores foram poderosos instrumentos de ordenação do mundo indígena para incorporá-lo progressivamente à civilização cristã ocidental. Reconhecemos, igualmente, que os missionários desenvolveram constantemente mecanismos de controle das interpretações possíveis e aceitáveis. Por outro lado, para que se torne convincente e verossímil, todo sentido depende de um acordo sobre os signos utilizados e, portanto, ele é necessariamente intersubjetivo, expressando-se na experiência comum compartilhada e no exercício comum da linguagem.

Pierre Bourdieu já demonstrou que a prática não pode ser deduzida exclusivamente das regras ; ela deve ser tomada, ao contrário, como uma improvisação, como um aprendizado do uso de determinadas regras, no qual as "maneiras de ver e o contexto estão associados e se implicam mutuamente" (BOURDIEU, 1990: 21). Nessa perspectiva, acreditamos que as manifestações de devoção registradas nas Cartas Ânuas, além de apontarem para a ressignificação de práticas e representações tradicionais guaranis, devem ser tomadas como resultantes de jogos de relações sociais e de comunicação, nos quais os indivíduos em interação, embora pertencentes a universos culturais distintos, necessariamente compartilharam símbolos, códigos e experiências. Somos, em razão disso, levados a concordar com Melià, para quem o êxito das reduções jesuíticoguaranis não se deu "apesar do que eram os Guaranis, senão precisamente pelo que eram estes Guaranis” (MELIÁ, 1986: 209).

\section{BIBLIOGRAFIA}

BOURDIEU, Pierre. Coisas Ditas. São Paulo: Brasiliense,1990

CABEZA DE VACA, Alvar Núñez. Naufrágios e Comentários. Madrid: História 16, 1984.

CAILLOIS, Roger. O homem e o sagrado. Lisboa: Edições 70, 1988.

CAMPOS, Adalgisa Arantes. Irmandades Mineiras e Missas. Belo Horizonte: Vária História, n. 16, p. 66-76, set. 1996.

CARTAS ÂNUAS DE LA PROVÍNCIA DEL PARAGUAY. C. A. [1663]. Traducción de Carlos Leonhardt, SJ. Buenos Aires, 1927 (mimeo). 
CARTAS ÂNUAS DE LA PROVÍNCIA DEL PARAGUAY. C. A. [1672-1675]. Traducción de Carlos Leonhardt, SJ. Buenos Aires, 1927 (mimeo).

CARTAS DE INDIAS. Biblioteca de Autores Españoles. Madrid: Editora Atlas, 1877.

CERTEAU, Michel de. Artes de fazer. Invenção do cotidiano. Petrópolis: Vozes, 1994.

CHARTIER, Roger. A História Cultural - Entre Práticas e Representações. Lisboa: DIFEL ; Rio de Janeiro: Bertrand,1990.

CORRÊA, Rosita Paneiro. O Teatro Colonial Brasileiro. In: NUÑEZ, Carlinda F. et alii. $O$ teatro através da história. O Rio de Janeiro: Centro Cultural Banco do Brasil, 1994, v. 2, p. 16-32.

DEL PRIORE, Mary. Deus dá licença ao Diabo: a contravenção nas festas religiosas e igrejas paulistas no século XVIII. In: VAINFAS, R. (org.). História e Sexualidade no Brasil. Rio de Janeiro: Graal, 1986, p. 90-113.

DOCUMENTOS PARA LA HISTORIA ARGENTINA (Cartas Ânuas de la Província del Paraguay, Chile y Tucumán de la Província de la Compañía de Jesús - 1615-1637, tomo XX, Buenos Aires, Talleres Casa Jacobo Preuser, 1927.

DURKHEIM, Emile. As Formas Elementares da Vida Religiosa. São Paulo: Ed. Paulinas, 1989.

FURLONG, Guillermo S.J. Misiones y sus Pueblos de Guaraníes. Buenos Aires: Theoria, 1962.

GRUZINSKI, Serge. Do Barroco ao Neobarroco. Fontes Coloniais dos Tempos Pós-Modernos. 0 caso mexicano. In: CHIAPPINI, Lígia e AGUIAR, Flávio Wolf de. (org.) Literatura e História na América. São Paulo: EDUSP, 1993.

KARNAL, Leandro. Teatro da Fé: Representação religiosa no Brasil e no México do séuclo XVI. São Paulo: HUCITEC, 1998.

KERN, Arno Alvarez. Missões: Uma Utopia política. Porto Alegre: Marcado Aberto, 1982.

LEBRUN, François. As Reformas: devoções comunitárias e piedade pessoal. In: Ariés, Pierre (org.) História da vida privada. (Vol. 3). São Paulo: Cia. das Letras, 1991.

LEITE, Serafim (org.). Cartas dos Primeiros Jesuitas Brasileiros. São Paulo,1954.

LOPES, Eliane ; FARIA FILHO, Luciano ; VEIGA, Cynthia. (orgs.). 500 Anos de Educação no Brasil. Belo Horizonte: Autêntica, 2000.

LOZANO, Pedro. Historia de la Conquista del Paraguay. Buenos Aires: Casa Editora Imprenta Popular, 1973.

MAEDER, Ernesto J. A. (org). Cartas Ânuas de la Província Jesuítica del Paraguay, 1641-1643.

Resistência, Instituto de Investigaciones Geohistoricas, 1996.

MAEDER, Ernesto J. A. (org.) Cartas Anuas de la Provincia del Paraguay, 1632 - 1634. Buenos Aires, FECIC, 1990.

MAEDER, Ernesto J. A.(org.) Cartas Ânuas de la Provincia del Paraguay, 1637 - 1639. Buenos Aires, FECIC - Fundación para la Educación, la Ciencia y la Cultura, 1984.

MANUSCRITOS DA COLEÇÃO DE ANGELIS. MCA I. Tomo I. Rio de Janeiro, Biblioteca Nacional, 1951. (Jesuítas e Bandeirantes no Guairá (1549 - 1640).

MARTINI, Monica.Imagem del diablo en las reducciones guaranies. Revista Investigaciones y Ensaios, Buenos Aires, n. 40, p. 175-227,1990.

MELIÁ, Bartomeu. El Guarani Conquistado y Reducido. Biblioteca Paraguaya de Antropología, v. 5. Centro de Estudios Antropológicos. Universidad Católica, Asunción, 1986. 
MONTOYA, Antonio Ruiz de. Conquista Espiritual. Porto Alegre, Martins Livreiro, 1985.

MONTOYA, Antonio Ruiz de. La Gran "Conquista Espiritual” del Paraguay. Rosario, Equipo Difusor de Estudios de Historia Iberoamericana, 1989.

RABUSKE, Arthur S.J. A Carta Magna das Reduções do Paraguai. Estudos Leopoldenses, São Leopoldo, 1978, a. XIII, v. 14, n. 47, p. 21-39.

SCHMITT, Jean-Claude. História das Superstições. Mira-Sintra: Publicações Europa-América, 1997.

SEPP, Antonio S.J. Viagem às Missões Jesuíticas e Trabalhos Apostólicos. Belo Horizonte, Editora Itatiaia/São Paulo: Editora da Universidade de São Paulo, 1980.

SUSNIK, Branislava. Guerra, Trânsito, Subsistência. Asunción, Manuales del Museo Etnográfico Andres Barbero, 1990.

SUSNIK, Branislava. La cultura indigena y su organización social dentro de las misiones jesuiticas. Asunción: Suplemento Antropológico, v. XIX, n. 2, deciembre 1984.

VIVEIROS DE CASTRO, Eduardo. O mármore e a murta: sobre a inconstância da alma selvagem. Revista de Antropologia, USP, São Paulo, v. 35, p. 21-74, 1992.

\section{NOTAS}

1. A antiga Província do Paraguay abrangia, na época colonial, limites bastante mais extensos que os da atual República Paraguaia, recebendo o nome do rio que a banhava e compreendeendo uma imensa região que se estendia entre o Brasil e o Peru, até o Prata e o Oceano Atlântico. 0 antigo Paraguay limitava-se, ao norte, com a Capitania de São Vicente, pois a linha imaginária a separar os territórios de Portugal passava sobre o Iguape, no atual Estado de São Paulo ; ao sul, com o Rio da Prata ; a leste com o Oceano Atlântico e a oeste com a Província de Tucumán, atualmente território argentino. Os atuais Estados brasileiros do Paraná, Santa Catarina, Rio Grande do Sul e sul do Mato Grosso, subindo daí até a bacia do Amazonas, eram jurisdição do Paraguay. O Uruguai e a Argentina, com exceção de Tucumán, igualmente estavam sob sua jurisdição. No atual território boliviano, o Paraguay limitava-se com a Província de Santa Cruz de la Sierra.

2. Esta preocupação é observável na normatização que os padres observavam, já que havia um lugar e um tempo próprio para cada ritual ; havia um dia da semana específico para o batismo, outro para casamentos, dias determinados para confissões e o momento exato do dia ou da missa em que deveriam ocorrer. A disposição dos fiéis na igreja também obedecia a regras : antes da missa, as crianças separadas em filas por sexo, cantavam no átrio e repetiam orações em voz alta. Depois, entravam na igreja pelas portas principais, as mulheres adultas e, pelas laterais, os homens. A nave central era ocupada pelas autoridades, civis (cabildantes, guerreiros e caciques) que tinham direito a cadeiras e podiam assistir sentados à missa. $O$ resto da comunidade podia sentar-se no chão ou assistir ao ofício de joelhos. Atrás das autoridades civis ficavam os rapazes e, mais ou menos dois metros atrás, acomodavam-se as moças, evitando que houvesse até mesmo um contato visual entre estes. No fundo e nas naves laterais se colocavam as mulheres, e no espaço que sobrava espalhavam-se os homens. Durante toda a missa havia pessoas responsáveis por fiscalizar o comportamento dos índios.

3. Conforme Mónica Martini, "desde esta perspectiva el Paraguay, como toda la América Hispana, aparecía ante los ignacianos como un reducto del infierno donde Satanás, monarca absoluto e inspirador de creencias y supersticiones paganas, tenía sojuzgadas las almas de los guaraníes." (MARTINI, 1990: 135)

4. Há que considerar que os jesuítas entendiam-se como novos apóstolos, que à semelhança da conversão dos pagãos, realizada por eles na Europa, fariam ver àquela gente cega os erros em que viviam e os pecados que cometiam. 
5. Cabe aqui ressaltar que a ação da Igreja contra as superstições ao longo da Idade Média e no período moderno era comandada por prerrogativas sociais, que se inscreviam num vasto programa de reforma religiosa e moral. Logo, "a sua vontade de impor uma ordem social era inseparável da preocupação propriamente pastoral de salvar as almas”. (SCHMITT, 1997: 10). É oportuno também lembrar que as virtudes fundamentais do cristão eram a fé, a castidade e a caridade, sendo que o batismo, além de constituir-se em rito de iniciação, era a garantia de retidão da vida do cristão.

6. Em relação às Cartas Ânuas deve-se observar que as "Litterae Anuae" eram a correspondência periódica que os Padres Provinciais enviavam ao Padre Geral da Companhia de Jesus. Elas têm sua base nos relatórios anuais que o Provincial recebia dos superiores das Residências, Colégios, Universidades e Missões junto aos índios. Continham uma detalhada informação sobre as Casas de Formação, suas obras, pessoas e atividades. As Cartas Ânuas, relativas à Província Jesuítica do Paraguai, cobrem o período que vai de 1609 a 1675 e, após um intervalo de cerca de 40 anos, o período de 1714 a 1762 .

7. Hansen nos lembra que "nos séculos XVI e XVII, nas missões jesuíticas [...] a iniciativa de fazer da pregação oral o instrumento privilegiado de divulgação da Palavra divina pressupunha que a luz natural da Graça inata ilumina a mente dos gentios - objeto da catequese -, tornando-os predispostos à conversão." (HANSEN In: LOPES, 2000: 21)

8. Cabe lembrar que a religião cristã foi "presentada de tal forma que llega a ritualizar todas las actividades del día y ofrece una extensa e intensa cerimonialidad", como a observada nas procissões, por exemplo. (MELIÀ, 1986: 210).

9. O sagrado aparece neste registro "como uma categoria da sensibilidade", sobre a qual se assenta " $a$ atitude religiosa", que "impõe ao fiel um sentimento de respeito particular", resultante, "simultaneamente de terror e confiança". Ao mesmo tempo, constitui-se em recurso "para influenciar a vida real, para se garantir todos os efeitos desejáveis do favor divino". (CAILLOIS, 1988: 20, 22,159).

10. É válido lembrar "a crença no poder expiatório da missa, considerada a mais sublime oração nos diversos níveis culturais da época moderna. [...] Antes mesmo da Reforma, a missa constitui o rito central do Cristianismo na Europa. Muito divulgada é a crença em seu poder expiador, reparador e na sua eficácia para aplacar a ira divina e alcançar a pacificação no plano social, a elevação espiritual e, notadamente, a salvação da alma.” (CAMPOS,1996: 66).

11. Os missionários encontraram na cultura indígena um "substrato artístico que consistia basicamente em demonstrações rítmicas de música (cantada e/ou instrumental) e dança, com estreitos vínculos religiosos [...] entre os tupinambás e os tupis-guaranis. Tais índios eram bastante voltados para as práticas mágicas, e uma delas constituía verdadeiro espetáculo de animação de marionetes, desenvolvida pelo pajé com o fim particular de conseguir a multiplicação miraculosa das serpentes. Além disso, faziam cortejos, espécies de procissões com danças, como a que era executada para chamar a chuva ou a cerimônia das magias que favoreciam um aumento da produção do algodão". (CORRÊA In: NUÑEZ, 1994: 24). Os missionários jesuítas logo perceberam como os índios apreciavam a música, a dança, canto, os ritos, as festas e os espetáculos, combinando-os com as formas simples e livres dos Autos de tradição medieval.

12. Ver mais em CAILLOIS,1988: 97.

13. Com efeito, a igreja será, no contexto das reduções jesuítico-guaranis, o espaço privilegiado para a introdução de novos valores, enquanto espaço de oração e de súplica pelos já convertidos e, sobretudo, enquanto espaço sagrado de realização de milagres.

14. Segundo Del Priore, a Igreja abriga "a dicotomia de um código rígido de comportamento de uma excessiva concentração de indivíduos que põe à prova a eficácia deste código". (DEL PRIORE In: VAINFAS, 1986: 96)

15. Conforme observou Meilià, "la reducción, toda ella orientada sobre la plaza y esta mirando a la iglesia, oferecía una estructura apropiada para lo que podría llamarse una socialización sacralizada". (MELIÀ,1986:195) 
16. Durkheim, numa referência à instituição universal do descanso religioso, observa que "o caráter distintivo dos dias de festa corresponde, em todas as religiões conhecidas, à pausa no trabalho, suspensão da vida pública e privada, à medida que estas não apresentam objetivo religioso. Mas é que o trabalho é a forma eminente da atividade profana: não tem outro objetivo evidente senão prover às necessidades temporais da vida [...] Ao contrário, nos dias de festa, a vida religiosa atinge grau de excepcional intensidade". Segundo o autor, "a vida religiosa e a vida profana não podem coexistir nas mesmas unidades de tempo". Todas as sociedades cristãs-ocidentais conhecem e praticam "essa divisão do tempo em duas partes estanques, alternando uma com a outra conforme uma lei variável de acordo com os povos e as civilizações [...]". (DURKHEIM, 1989: 371 - 373). Ao transpormos essas considerações para os castigos divinos que se abatem sobre os faltantes às festas ou às missas nas reduções, deve-se considerar que as doenças ou as mortes que sobrevêm são registradas pelos missionários como conseqüência natural das transgressões. Deve-se, no entanto, ressaltar que esta impossibilidade de coexistência, ao mesmo tempo, do sagrado com o profano é desconhecida das sociedades indígenas ; em razão do que ocorriam as transgressões que devem ser percebidas muito mais como decorrência natural do "modo de ser" Guarani, do que como resultantes, exclusivamente, de uma resistência consciente aos princípios cristãos pregados pelos missionários.

17. Cabe ressaltar que para Max Weber existe uma importante margem de liberdade de ação para os homens, que são dotados de vontade subjetiva e com base nisso conduzem suas ações. Essa vontade subjetiva está sempre vinculada a ações de outros homens, isto é, obedece aos limites das possibilidades que se apresentam junto às ações - tradicionais, afetivas e/ou racionais - de outros. Vale ressaltar que mesmo quando as ações são caracterizadas como tradicionais realizadas mais mecanicamente pela repetição dos costumes -, na realidade, não se constituem como tipos puros e dependem, de forma variável, também de interesses racionais e/ou afetivos.

18. Susnik, em artigo sobre a cultura indígena e sua organização social dentro das missões jesuíticas, observa que "música, danzas religiosas y simbólicas, oraciones cantadas, solemnidad de domingos, celebración de fiestas religiosas [...] fueron ocasiones propícias para dar a la muchedumbre un desahogo psico-emocional tanto colectivo como individual, [...] el nuevo patrón emocional se basaba en factores puramente impresivos y audio-visuales, en pleno contraste con la antigua participación vivencial de las danzas sagradas.". A antropóloga enfatiza que para os Guarani "estas expresiones no eran mas que una 'faena' agradable a su natural ambición psicomental”. (SUSNIK, 1984: 16)

\section{RESUMOS}

A produção discursiva jesuítica dos séculos XVI e XVII revela a preocupação que os missionários tiveram em definir as inclinações favoráveis e as inaptidões naturais dos indígenas, e, também, em justificar sua utilização ou erradicação para o êxito do projeto de civilização e de evangelização. Mergulhados na mística salvacionista da Contra-Reforma, estes religiosos não se furtaram em registrar o seu estranhamento e a condenação de determinadas práticas culturais, bem como sua incompreensão em relação aos rituais que as envolviam. Neste artigo, privilegiamos a análise desta documentação, buscando identificar a eventual utilização estratégica destas manifestações para a introdução da ritualística e da sensibilidade devocional cristã por alguns missionários que atuaram na Província Jesuítica do Paraguai. 
La production discursive des Jésuites des XVIe et XVIIe siècles révèle la préoccupation des missionnaires à définir les inclinations favorables et les inaptitudes naturelles des indigènes, et, en outre, à justifier leur utilisation ou éradication pour le succès du projet de civilisation et d'évangélisation. Plongés dans le mystique salutiste du Contre-réforme, ces religieux ne se sont pas contentés à enregistrer leur étrangeté, mais ils ont condamné certaines pratiques culturelles en raison de leur incompréhension des rituels. Dans cet article, nous privilégions l'analyse de cette documentation, en cherchant à identifier la possible utilisation stratégique de ces manifestations, pour l'introduction de la sensibilité de dévotion rituelle chrétienne par quelques missionnaires travaillant dans la Province Jésuite du Paraguay.

\section{ÍNDICE}

Palavras-chave: Cartas Ânuas, Província Jesuítica do Paraguai, ritualística cristã, sensibilidade religiosa, missas, procissões, festas religiosas

Mots-clés: lettres annuelles, province jésuite du Paraguay, rituels chrétiens, sensibilité religieuse, messes, processions, fêtes religieuses

\section{AUTOR}

\section{ELIANE CRISTINA DECKMANN FLECK}

Doutora em História - UNISINOS, São Leopoldo, RS

ecdfleck[at]terra.com.br 